\title{
Discussion: Re-evaluation of the reliability of hardened concrete analyses
}

David B. Crofts BSC, PhD, CChem, MRSC, DIC, ARCS Associate Director, RSK Environment Ltd, Hemel Hempstead, UK Iren Jasko MSc, EurChem, CSci, CChem, FRSC Technical Manager, Quartz Scientific, Watford, UK

Gavin Mayers BSC, MSc, CChem, MRSC

Partner, Sandberg LLP, London, UK
Jeremy P. Ingham BSC, MSC, DipRMS, CEng, MInstNDT, EurGeol, CGeol, CSci, FCS, FGS, FRGS, FRMS

Associate Director, Mott MacDonald Ltd, Special Services Division, Croydon, UK

Richard Barnes MPhil, PhD, CEng, MICE, MICT, FHEA, Eur Ing Advisory Engineer, The Concrete Society, Camberley, UK

\section{Contribution by J. P. Ingham and R. Barnes}

The Concrete Society considers the Briefing by Crofts et al. (2015) to contain misleading statements. The Briefing was first published online ahead of print on 3 May 2016 (Crofts et al., 2015). Shortly after this, the Concrete Society raised 14 points of contention with the authors (through the journal), and they amended their article to address five of these. The remaining nine were not addressed and no adequate explanation was provided as to why. This revised version was then republished online, replacing the original, but with no notification of the changes being provided to the readership. Hence, there are now two different versions of the online PDF publication in circulation. The revised version was eventually published in the printed edition of the journal in December 2015 (Crofts et al., 2015).

The Concrete Society is keen to make the readership aware that the Crofts et al. (2015) Briefing (in any of the three circulating versions) in no way represents their opinion. The laboratory trial that is the subject of the Briefing by Crofts et al. (2015) was a laboratory trial conducted under the supervision of the Concrete Society's Materials Standing Committee as part of the revision of the first edition of Technical Report 32 (TR32) (Concrete Society, 1989). Full details of the trial were published in the second edition of TR32 (Concrete Society, 2014), and a detailed summary of the findings was published earlier as a two-part article in the society's magazine, Concrete (Barnes and Ingham, 2013, 2013/2014). A Concrete Societyapproved Briefing (Ingham and Barnes, 2015) was subsequently published in the same edition of Proceedings of the Institution of Civil Engineers - Construction Materials as the Crofts et al. (2015) Briefing.

Crofts et al. (2015) claim (in Section 1, paragraph 3) that the limitations of the laboratory trial were not discussed at length within the TR32, second edition. It is felt that this is somewhat ungenerous, as the principal limitation was clearly stated (extract from TR32, second edition) and the others can be inferred from the recommendations for further trials as listed in Sections 5 and D5 of TR32, second edition

$$
\begin{aligned}
& \text { It is important to acknowledge the limitations of the laboratory } \\
& \text { trial described in this Report [TR32], in particular the relatively } \\
& \text { small size of the data sets used, which may reduce the accuracy of } \\
& \text { estimations of the inherent repeatability and reproducibility } \\
& \text { (Concrete Society, 1989). }
\end{aligned}
$$

The Concrete Society maintains that the design of its laboratory trial was fundamentally sound. While the laboratory trial could have been improved by the testing of more samples, it was nevertheless the largest and most comprehensive of its type ever undertaken, and as such, represents the best data collection available. It should also be noted that, in addition to participating in the laboratory trial, Crofts et al. (2015) were involved in the design of the trial at all stages and approved it in principle.

Crofts et al. (2015) suggest (in Section 3, paragraph 3) that the use of three batches of concrete per mix and $100 \mathrm{~mm}$ cube samples was a reason for the considerable variability in the determined results. The Concrete Society fails to see how the use of $100 \mathrm{~mm}$ cubes (a specimen size agreed on by the Concrete Society Working Group that included Crofts et al. (2015)) could have contributed to the variability of the results. The three batches of concrete per mix design gave very little variation in compressive strength, indicating that they were very similar concretes. For mix 4, for example, the $28 \mathrm{~d}$ cube strengths of the three batches ranged from 47 to $50 \mathrm{MPa}$, while the laboratory analysis for water/cement ratios gave values ranging from $0 \cdot 4$ to $0 \cdot 9$.

Figures 1 and 2 in the Crofts et al. (2015) Briefing could be interpreted to support the view that sample preparation has a large influence on results. A sample taken from cube A and 
tested repeatedly gives more repeatable results than a sample from cube A or a sample from cube B. What is not shown in Figures 1 and 2 is the repeatability of the results between separately prepared samples from the same cube.

Crofts et al. (2015) suggest (in Section 2, paragraph 6) that the results from the trial provide evidence that cement-content analysis becomes more reliable when reference aggregates are made available as part of the analysis. Although trial data indicated a slight improvement in accuracy for one of the concrete mixes (containing limestone aggregate), this was not found to be the case for the concrete mixes containing insoluble aggregate combinations. Regarding the authors' statement that 'For the mixes containing insoluble aggregate combinations, there was no improvement in the results obtained by RSK', this disguises the facts in that $66 \%$ of results were actually worse (see Table D9 in TR32, second edition), which is counter-intuitive to the reason for including a reference aggregate. For the determination of the water/cement ratio, when aggregate references were made available to the laboratory, the accuracy was reduced for $63 \%$ of the results (see Table D10 of TR32, second edition).

The discussion contributors point out that the 'new' laboratory trial that Crofts et al. (2015) plan to organise (as set out in Section 3) appears to be considerably more limited in scope than the Concrete Society trial. As such, it is unlikely to adequately address all the issues, and this would represent an opportunity missed. A much more ambitious trial is needed as described in Concrete Society TR32, second edition.

Crofts et al. (2015) assert (in Section 4) that the BS 1881-124 (BSI, 1988) analytical methods have been 'used successfully for many years'. It is important to note that the converse is likely to be the case, as evidence provided by the Concrete Society laboratory trial (the only significant trial of BS 1881-124 (BSI, 1988) methods applied to contemporary concrete) indicates that the routine procedures (sampling, preparation, analysis) used for decades may have been providing inaccurate results.

In conclusion, the findings of the Concrete Society laboratory trial indicated that there is significant doubt regarding the accuracy of the BS 1881-124 (BSI, 1988) analysis procedures when applied to contemporary concrete. This is a matter of considerable concern, as the BS 1881-124 (BSI, 1988) analysis methods are routinely used in the condition surveys and the forensic engineering of concrete infrastructure in the UK and overseas.

\section{Authors' reply}

This contribution has been prepared in response to Ingham and Barnes (2015) writing on behalf of the Concrete Society regarding what they considered to be misleading statements in the Briefing by Crofts et al. (2015). Following the appearance of the latter online ahead of print, a number of points of contention were raised by Ingham and Barnes (2015) on behalf of the Concrete Society. Prior to the publication of the paper in print in December 2015, six of the 13 points were addressed, including corrections of points of fact and rewording where misinterpretation was possible. In addition, disclaimers were added to clarify that, in writing the paper, the authors were not representing the Concrete Society or its opinion.

The continued interest in the proposals is welcomed, and the current discussion has been prepared to respond to the seven points that Ingham and Barnes (2015) indicate remain in contention.

Although the limitations of the laboratory trial could be inferred from the recommendations for further trials in Section 5 and D5 in TR32 (Concrete Society, 2014), and the relatively small sizes of the data sets used were acknowledged at the end of D4. 1 therein, it was felt that the results and conclusions drawn from them merited a more in-depth assessment of these limitations.

It was felt that one of the limitations that warranted further investigation was the use of three batches per mix and $100 \mathrm{~mm}$ cube specimens. None of the cube strength data for any of the batches or mixes has been provided. However, a cube strength value is just that and does not provide any information about a concrete mix. The Society of Chemical Industry (SCI) trial currently being undertaken is designed in part to avoid any variation among the specimens as a result of using multiple mixes per batch.

Figures 1 and 2 in the Briefing (Crofts et al., 2015) could allow more than one interpretation and were included to show how internal precision data had alerted the participants to potential problems. The SCI trial currently underway is designed to include the investigation of duplicate testing of separately prepared samples from the same cube.

The Briefing paper (Crofts et al., 2015) pointed out that when the mix contained limestone aggregate, the provision of a reference sample improved the accuracy of the determination of cement content. Two of the mixes containing insoluble aggregates also included mineral additions (pulverised-fuel ash (PFA) or ground granulated blastfurnace slag (GGBS)), reference samples of which were not provided. Without these references, the analysis of aggregate references is unlikely to improve accuracy.

The wide-ranging Concrete Society laboratory trial having raised concerns about more than one aspect of the BS 1881-124 methods (BSI, 1988), it appeared prudent to 
undertake a trial that was more limited in scope, in order to establish whether the method was still applicable to 'ordinary' concrete. The current trial is designed to identify where the errors may have occurred that led to the concerns raised by the Concrete Society trial.

Given the range of mixes used in the Concrete Society laboratory trial, it is hoped that a simpler trial will establish whether the methods that have been in use for many years are capable of providing accurate results.

It is agreed that the Concrete Society findings raised issues with the methods in use. It is hoped that completion of the current precision experiment will be able to resolve at least some of these concerns.

\section{REFERENCES}

Barnes R and Ingham J (2013) The chemical analysis of hardened concrete: results of a round robin trial, part 1. Concrete Magazine, October: 45-48.

Barnes R and Ingham J (2013/2014) The chemical analysis of hardened concrete: results of a round robin trial, part 2. Concrete Magazine, December/January: $48-51$.

BSI (1988) BS 1881-124: Testing concrete. Part 124 - methods for analysis of hardened concrete. BSI, London, UK.

Crofts DB, Jasko I and Mayers G (2015) Briefing: Re-evaluation of the reliability of hardened concrete analysis. Proceedings of the Institution of Civil Engineers - Construction Materials 168(6): 259-262, http://dx.doi.org/10.1680/coma. 15.00026.

Concrete Society (1989) Analysis of Hardened Concrete: A Guide to the Tests, Procedures and Interpretation of Results. The Concrete Society, Camberley, UK, Technical Report No. 32, Report of a Joint Working Party of the Concrete Society and Society of Chemical Industry.

Concrete Society (2014) Analysis of Hardened Concrete: A Guide to Test Procedures and Interpretation of Results, 2nd edn. The Concrete Society, Camberley, UK, Technical Report No. 32.

Ingham J and Barnes R (2015) Briefing: Testing times for concrete structures - is BS 1881-124 still fit for purpose? Proceedings of the Institution of Civil Engineers Construction Materials 168(6): 253-258, http://dx.doi.org/ 10.1680/coma.14.00061. 